Article

\title{
Tuning the product selectivity of SAPO-18 catalysts in MTO reaction via cavity modification
}

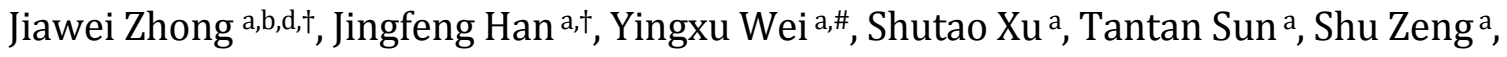

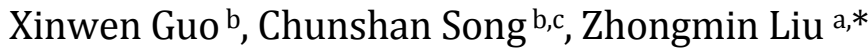 \\ a National Engineering Laboratory for Methanol to Olefins, State Energy Low Carbon Catalysis and Engineering R\&D Center, Dalian National Laboratory \\ for Clean Energy, iChEM (Collaborative Innovation Center of Chemistry for Energy Materials), Dalian Institute of Chemical Physics, Chinese Academy of \\ Sciences, Dalian 116023, Liaoning, China \\ b State Key Laboratory of Fine Chemicals, PSU-DUT Joint Center for Energy Research, School of Chemical Engineering, Dalian University of Technology, \\ Dalian 116024, Liaoning, China \\ c EMS Energy Institute, Departments of Energy and Mineral Engineering, and of Chemical Engineering, The Pennsylvania State University, University Park, \\ PA 16802, USA \\ d University of Chinese Academy of Sciences, Beijing 100049, China
}

\section{A R T I C L E I N F O}

\section{Article history:}

Received 13 November 2018

Accepted 19 December 2018

Published 5 April 2019

\section{Keywords:}

SAPO-18

Methanol to olefin

Cavity modification

Product selectivity

\begin{abstract}
A B S T R A C $\mathrm{T}$
The AEI cavity of SAPO-18 catalyst was modified with zinc cations with the conventional ion exchange procedure. The cavity modification effectively tunes the product selectivity, and shifts the products from mainly propylene to comparable production of ethylene and propylene in methanol to olefin (MTO) reaction. The incorporation of zinc ions and the generation of bicyclic aromatic species in the AEI cavity of SAPO-18 catalysts introduce additional diffusion hindrance that exert greater influence on the relatively bulky products (e.g. propylene and higher olefins), which increase the selectivity to small-sized products (e.g. ethylene). It appears that the incorporated zinc cations facilitate the generation of lower methylbenzenes which promote the generation of ethylene. The cavity modification via incorporating zinc ions effectively tunes the product selectivity over SAPO molecular sieves with relatively larger cavity, which provides a novel strategy to develop the potential alternative to SAPO-34 catalysts for industrial MTO reaction.
\end{abstract}

(C) 2019, Dalian Institute of Chemical Physics, Chinese Academy of Sciences. Published by Elsevier B.V. All rights reserved.

\section{Introduction}

Light olefins, including ethylene and propylene, as important chemicals, have a plethora of applications in the current petrochemical industry. In the regions with a plenty of coal and natural gas, the methanol-to-olefin (MTO) reactions have attracted great interest [1-4]. In particular, SAPO-34, the ar- chetypal MTO catalyst, displays satisfying catalytic performance and high selectivity to light olefins in the MTO reactions, attributed to the eight-membered ring ( $8 \mathrm{MR}$ ) pore openings $(3.8 \times 3.8 \AA)$ and CHA cavity $(6.7 \times 10.9 \AA)$, medium-strong acidity, as well as the high thermal and hydrothermal stability [5-7]. The hydrocarbon pool (HCP) mechanism is widely accepted in MTO reaction, and the polymethylbenzenium cation

\footnotetext{
* Corresponding author. Tel: +86-411-84379998; Fax: +86-411-84379289; E-mail: liuzm@dicp.ac.cn

\# Corresponding author. Tel: +86-411-84379118; Fax: +86-411-84379289; E-mail: weiyx@dicp.ac.cn

† Contributed equally to this work.

This work was supported by the Key Research Program of Frontier Sciences, CAS (QYZDY-SSW-JSC024), the National Natural Science Foundation of China $(21603223,21473182,91334205,91545104)$, and the Youth Innovation Promotion Association of the CAS (2014165).

D0I: S1872-2067(19)63281-X | http://www.sciencedirect.com/science/journal/18722067 | Chin. J. Catal., Vol. 40, No. 4, April 2019
} 
and polymethylcyclopentadienium cation are usually considered as the HCP species [1,2,8-10].

It is widely accepted that the cavity structure and pore size of molecular sieve exert great impacts on the product selectivity in the methanol to hydrocarbons (MTH) reaction [11]. In particular, the cavities of SAPO with 8 MR pore openings exert significant confinement impacts on product distribution in MTO reaction. For instance, the cavity of SAPO-18 (AEI cavity) and SAPO-34 (CHA cavity) provide enough space to accommodate the polycyclic aromatic species (Fig. 1), which results in the main formation of propylene and butylene for SAPO-18, ethylene and propylene for SAPO-34, respectively. By contrast, the cavity of SAPO-35 (LEV cavity, $6.3 \times 7.3 \AA$ ) inhibit the generation of bulky aromatic organics species, leading to the formation of ethylene and propylene, especially ethylene [12]. Similarly, the cavity size of DNL-6 ( $\alpha$ Cavity, $11.4 \times 11.4 \AA$ ), SAPO-35 and SAPO-34 influence the molecular size and activity of the confined polymethylbenzenium cations (polyMB ${ }^{+}$) and polymethylcyclopentenyl cations (polyMCP+), leading to different catalytic activity and product selectivity in MTO reaction. Butylene and ethylene are the major products over DNL-6 and SAPO-35, respectively, while ethylene and propylene are mainly produced over SAPO-34 [13]. Considering the fact that propylene currently shows relatively lower economic value than ethylene, and the by-products of $\mathrm{C} 4+$ in industrial MTO process are further recycled and cracked to ethylene and propylene so as to improve the economic profits [1]. Therefore, it is important to tune the product selectivity and enhance the selectivity of light olefins, especially ethylene in the MTO reaction over SAPO molecular sieves with relatively larger cavity (e.g. SAPO-18).

As a potential alternative MTO catalyst, various approaches such as the synthesis of MeASPO-18 [15,16], CHA/AEI intergrowth materials [17] as well as the core-shell SAPO-34@SAPO-18 composites [18] have been developed to enhance the catalytic activity of SAPO-18 catalysts. Recently, our group drawn the conclusion that the zinc ions accommodation as well as the facilitated generation of aromatic species over zinc ions modified SAPO-34 catalysts introduce extra diffusion hindrance for bulky hydrocarbons, which is beneficial for the enhancement of ethylene selectivity in MTO reaction [19-21]. Therefore, in this study, the AEI cavity of SAPO-18 was modified with zinc ions. The zinc ions promote the formation of the bicyclic aromatic species, which increases the diffusion limitation and switches the major formation of propylene to comparable production of ethylene and propylene. Furthermore, the zinc cations accommodations in the AEI cavities facil-

(a)
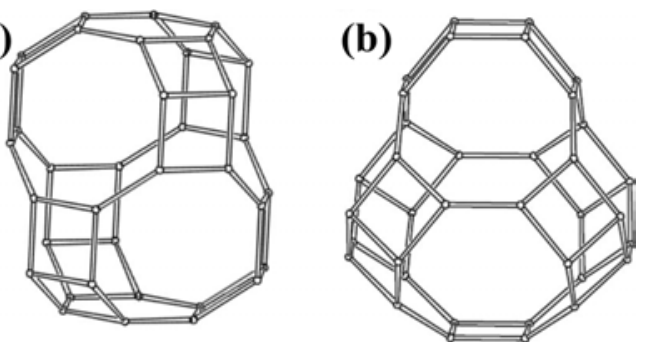

Fig. 1. (a) CHA cavity of SAPO-34; (b) AEI cavity of SAPO-18 [14]. itate the generation of specific HCP species such as the methylbenzenes with two or three methyl groups which are beneficial for the ethylene generation. A novel strategy to tune the product selectivity over SAPO molecular sieves with relatively larger cavity was proposed.

\section{Experimental}

\subsection{Catalyst preparation}

SAPO-18 was synthesized via hydrothermal crystallisation from aluminophosphate-based gel. $N, N$-diisopropylethylamine (DIPEA), colloidal silica, phosphoric acid and aluminum hydroxide were adopted as sources of template, silica, phosphorous and aluminium, and the molar ratio $\mathrm{Al}_{2} \mathrm{O}_{3}: \mathrm{P}_{2} \mathrm{O}_{5}: \mathrm{SiO}_{2}$ : DIPEA : $\mathrm{H}_{2} \mathrm{O}=1: 1: 0.6: 2.0: 50$. Crystallization was carried out in stainless steel autoclave at $170{ }^{\circ} \mathrm{C}$ for $48 \mathrm{~h}$. The solid sample was obtained after centrifugation, washing and drying at 100 ${ }^{\circ} \mathrm{C}$. The organic template was removed via calcination at $550{ }^{\circ} \mathrm{C}$ for $4 \mathrm{~h}$, the as-prepared sample is denoted as H-SP18 [22,23].

$\mathrm{H}-\mathrm{SP} 18$ was exchanged with $\mathrm{NH}_{4} \mathrm{NO}_{3}$ aqueous solution (1 mol/L) twice at $80^{\circ} \mathrm{C}$ for $2 \mathrm{~h}\left(1 \mathrm{~g} \mathrm{H}-\mathrm{SP} 18\right.$ in $10 \mathrm{~mL} \mathrm{NH}_{4} \mathrm{NO}_{3}$ aqueous solution) under stirring, followed by filtration, washing with deionized water, and drying in air at $100{ }^{\circ} \mathrm{C}$, the obtained powder was denoted as $\mathrm{NH}_{4}$-SP18. Then the $\mathrm{NH}_{4}$-SP18 was exchanged with $0.01 \mathrm{~mol} / \mathrm{L} \mathrm{Zn}\left(\mathrm{NO}_{3}\right)_{2} \cdot 6 \mathrm{H}_{2} \mathrm{O}$ aqueous solution at $50{ }^{\circ} \mathrm{C}$ for $4 \mathrm{~h}\left(1 \mathrm{~g} \mathrm{NH}_{4}-\mathrm{SP} 18 \text { in } 30 \mathrm{~mL} \mathrm{Zn(NO}\right)_{2} \cdot 6 \mathrm{H}_{2} \mathrm{O}$ aqueous solution). The solid powder was obtained after filtration, washing with deionized water, drying in air at $100{ }^{\circ} \mathrm{C}$, and calcination at $550^{\circ} \mathrm{C}$ for $4 \mathrm{~h}$. The obtained sample is denoted as Zn-SP18 [19,21].

\subsection{Catalyst characterization}

X-ray diffraction (XRD) were carried out in PANalytical X'Pert PRO diffractometer using a $\mathrm{Cu}$ tube equipped with monochromator ( $K_{\alpha}$ radiation, $40 \mathrm{kV}, 40 \mathrm{~mA}$ ) [19-21].

Scanning electron microscopy (SEM) was conduct with Hitachi TM3000 operated at $15 \mathrm{kV}[19,21]$.

Nitrogen adsorption-desorption measurements were carried out over Micromeritics ASAP 2020 at $-196^{\circ} \mathrm{C}$. Before the analysis, the samples were evacuated at $350{ }^{\circ} \mathrm{C}$ under vacuum. The total surface area was evaluated based on the Brunauer-Emmett-Teller (BET) equation. The surface area and microporous volume were calculated by the t-plot method [19-21].

The bulk chemical composition was determined with X-ray fluorescence (XRF) analyses carried out on a Philips Magix-601 spectrometer [19-21].

X-ray photoelectron spectroscopy (XPS) was performed on Thermo ESCALAB 250Xi. with a monochromatic Al $K_{\alpha}$ radiation (1486.6 eV, $15 \mathrm{kV}, 10.8 \mathrm{~mA}$ ). The binding energy (BE) values were referenced to the $\mathrm{C} 1 \mathrm{~s}$ peak of contaminant carbon $(284.8$ $\mathrm{eV}$ ). The atomic ratio of surface chemical compositions was determined with the peak areas of $\operatorname{Si} 2 p, \mathrm{Al} 2 p, \mathrm{P} 2 p$ and $\mathrm{Zn} 2 p$, respectively [19-21].

The temperature-programmed desorption of ammonia 
( $\mathrm{NH}_{3}$-TPD) were carried out in Micromeritics Autochem II 2920. The calcined sample was activated at $550^{\circ} \mathrm{C}$ for $1 \mathrm{~h}$ in $\mathrm{He}$ flow. Then the samples were cooled to $100{ }^{\circ} \mathrm{C}$, and subjected to a flow of $\mathrm{NH}_{3} / \mathrm{He}$ for $0.5 \mathrm{~h}$ to saturate the sample with $\mathrm{NH}_{3}$. The $\mathrm{NH}_{3}$ desorption was performed from 100 to $650{ }^{\circ} \mathrm{C}$ with the sample ramped at $10^{\circ} \mathrm{C} / \mathrm{min}$ in He flow [21].

The ${ }^{1} \mathrm{H}$ MAS NMR spectra were recorded on a Bruker Avance III 600 spectrometer equipped with a $4 \mathrm{~mm} \mathrm{H}-\mathrm{X}$ MAS probe. The resonance frequencies were tuned to $600.13 \mathrm{MHz}$ for broad band ${ }^{1} \mathrm{H}$ decoupling [19-21].

\subsection{Catalytic test}

The catalytic test was carried out in a quartz tubular fixed-bed reactor. The sample (1000 mg, 40-60 mesh) loaded in the fixed-bed reactor was activated at $500{ }^{\circ} \mathrm{C}$ in an Ar flow for $1 \mathrm{~h}$. Then the temperature was decreased to $480{ }^{\circ} \mathrm{C}$. The methanol aqueous solution with a $\mathrm{H}_{2} \mathrm{O} / \mathrm{CH}_{3} \mathrm{OH}$ weight ratio of $60 / 40$ was pumped into the quartz reactor, which gave a weight hourly space velocity (WHSV) of $2.0 \mathrm{~h}^{-1}$. The products were analysed by gas chromatograph (Agilent GC 7890A), with flame ionization detector (FID) and CP-PoraPlot Q-HT capillary column, thermal conductivity detector (TCD) and Porapak QS packed column. $\mathrm{CO}, \mathrm{CO}_{2}$ and $\mathrm{CH}_{4}$ were analysed by TCD, and hydrocarbons were analysed by FID. The conversion and selectivity were calculated on a carbon mole basis. Dimethyl ether was treated as reactant $[19,20]$.

\subsection{Initial period of MTO reaction}

Typically, $50 \mathrm{mg}$ catalysts loaded in the quartz tubular reactor were activated at $600{ }^{\circ} \mathrm{C}$ for $30 \mathrm{~min}$, subsequently the temperature was decreased to the reaction condition $\left(480^{\circ} \mathrm{C}\right)$. Flowing He (12.42 mL/min) was bubbled in methanol at $14^{\circ} \mathrm{C}$, which gave a WHSV of $2.0 \mathrm{~h}^{-1}$ [21]. The effluent products were saved in the 15 valve (Vici valco instruments) manually every $10 \mathrm{~s}$, and then analyzed by gas chromatograph (Agilent GC 7890B) using FID detector with capillary column HP-Plot/Q+PT (30 $\mathrm{m} \times 0.32 \mathrm{~mm} \times 20 \mathrm{um})$ and TCD detector with capillary column GS-CasPPO (30 $\mathrm{m} \times 0.32 \mathrm{~mm})$. The conversion and selectivity were calculated via the methods mentioned above.

\subsection{Diffusion properties}

The chromatographic method was adopted to analyse the diffusion properties of probe molecules in the catalyst bed. The samples were activated at $500{ }^{\circ} \mathrm{C}$ under helium for $30 \mathrm{~min}$. Pulse containing probing molecules (ethylene $4.87 \%$, or 1-butylene $4.90 \%$, helium gas as the background gas) was diffused into the catalyst bed of fresh or coked catalysts for just $0.6 \mathrm{~s}$, then the concentration of probing molecules was recorded via Mass Spectrometer Gas Analyzer (Pfeiffer Omnistar GSD 301 T3) [19,20].

The ethane adsorption isotherms were carried out in an intelligent gravimetric analyzer (IGA 100) from Hiden Isochema Ltd. Typically, the sample $(100 \mathrm{mg})$ was loaded into the micro- balance bag. Before the adsorption measurements, samples were degassed at $400{ }^{\circ} \mathrm{C}$ for more than $10 \mathrm{~h}$. The ethane isotherms were obtained at $20^{\circ} \mathrm{C}$. The curve of mass changes during the uptake process was determined at $10 \mathrm{mba}[19,21]$.

\subsection{Retained coke analysis}

The coke amount of catalysts was determined by thermogravimetry using SDT Q 600 analyzer in the temperature range from $25^{\circ} \mathrm{C}$ to $900{ }^{\circ} \mathrm{C}$ under flowing air. And catalysts after MTO reaction for $2 \mathrm{~min}$ at $480{ }^{\circ} \mathrm{C}$ were maintained isothermal at 150 ${ }^{\circ} \mathrm{C}$ for additional $0.5 \mathrm{~h}$ so as to completely remove the adsorbed water [19-21].

The carbonaceous species confined in the catalysts were analysed according to the dissolution/extraction process [24]. After dissolving the catalysts with $20 \%$ HF solution, the carbonaceous species in the samples were extracted with $\mathrm{CH}_{2} \mathrm{Cl}_{2}$ solution and then analysed using Agilent $7890 \mathrm{~A}$ gas chromatograph (FID detector, mass sensitive detector with HP-5 capillary column) $[19,20]$.

\section{Results and discussion}

\subsection{Crystallinity and textural property}

The XRD patterns of the H-SP18 sample confirm the pure phase of SAPO-18 (Fig. S1), and H-SP18 sample are composed of cubic crystals with sizes ranging from 1-2 $\mu \mathrm{m}$ (Fig. S2). After zinc cations modification, no phases related to $\mathrm{ZnO}$ are observed, implying the homogeneous distribution of zinc species in Zn-SP18 [25]. In addition, compared with H-SP18, quite slight decreases in pore volume and surface area are observed in Zn-SP18 (Table S1), indicating the preservation of textural property after the ion exchange process.

\subsection{Metallic state and metal distribution}

As shown in Fig. 2, Zn-SP18 show binding energy (BE) of Zn $2 p_{1 / 2}$ and $\mathrm{Zn} 2 p_{3 / 2}$ core level at 1045.8 and $1022.9 \mathrm{eV}$, respectively. Due to the lower electronegativity of the $\mathrm{O}^{2-}$ ligand in

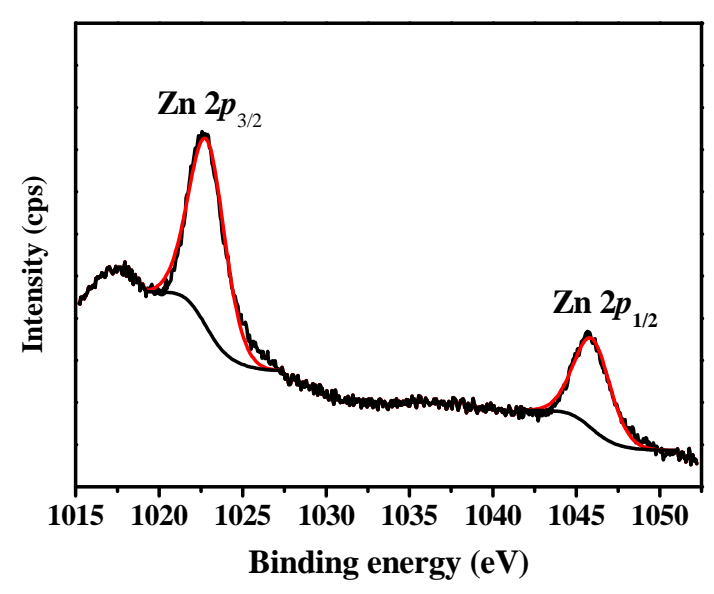

Fig. 2. XPS spectrum of Zn $2 p$ in Zn-SP18 catalyst. 
Table 1

The chemical compositions of H-SP18 and Zn-SP18.

\begin{tabular}{llll}
\hline Catalyst & Bulk & Surface & $R_{\mathrm{Si}} \mathrm{a} / R_{\mathrm{Zn}} \mathrm{b}$ \\
\hline H-SP18 (mol\%) & $\mathrm{Si}_{0.055} \mathrm{Al}_{0.493} \mathrm{P}_{0.452}$ & $\mathrm{Si}_{0.238} \mathrm{Al}_{0.401} \mathrm{P}_{0.361}$ & 3.7 \\
Zn content in & 0.35 & 0.96 & 2.7 \\
Zn-SP18 (wt\%) & & &
\end{tabular}

a The surface $\mathrm{Si}$ enrichment index $R_{\mathrm{Si}}$ is defined as $[\mathrm{Si} /(\mathrm{Si}+\mathrm{P}+$ $\mathrm{Al})]_{\text {surface }} /[\mathrm{Si} /(\mathrm{Si}+\mathrm{P}+\mathrm{Al})]_{\text {bulk; }}$; The surface $\mathrm{Zn}$ enrichment index $R_{\mathrm{Zn}}$ is defined as $\mathrm{Zn}_{\text {surface }} / \mathrm{Zn}_{\text {bulk. }}$

bulk $\mathrm{ZnO}$ than the lattice oxygen of zeolites, the bulk $\mathrm{ZnO}$ display lower BE than that of the $\mathrm{Zn}$ species at the exchangeable sites [26-28], thus the zinc species in Zn-SP18 are in the +2 valence state and stabilized at exchanged site [26-30].

The Si distributions in H-SP18 as well as the Zn distributions in Zn-SP18 are further investigated by a combination of XPS (Table 1) and XRF (Table S2). As shown in Table 1, the surface $\mathrm{Si}$ enrichment index $R_{\mathrm{Si}}$ is higher than 1, indicating the Si-enrichment near the external surface exists in H-SP18 $[1,31,32]$. Moreover, for $\mathrm{Zn}-\mathrm{SP} 18$, the calculated zinc content in the bulk $(0.35 \mathrm{wt} \%)$ is lower than that in the sublayer $(0.96$ $\mathrm{wt} \%$ ), indicating the incorporated zinc ions were basically located at the rim of the crystals [19-21].

\subsection{Catalytic performance}

As shown in Fig. 3, the cavity modification via zinc ions incorporation efficiently adjusts the product selectivity, and remarkably increases the selectivity to light olefins, especially ethylene. For example, after identical reaction time ( $2 \mathrm{~min}$ ), by contrast to H-SP18-2min, markedly increased ethylene selectivity (about 37\%) and selectivity to light olefins (about 77\%) are obtained over Zn-SP18-2min, with higher selectivity of ethylene and light olefins of approximately $7 \%$ and $5 \%$, respectively. In particular, Zn-SP18-2min and H-SP18-42min exhibit nearly identical product selectivity including the selectivity ethylene (Fig. S3), implying the high efficiency of cavity modification via zinc ions incorporation in the enhancement of selectivity to ethylene. Furthermore, Zn-SP18-HS (HS is short for the

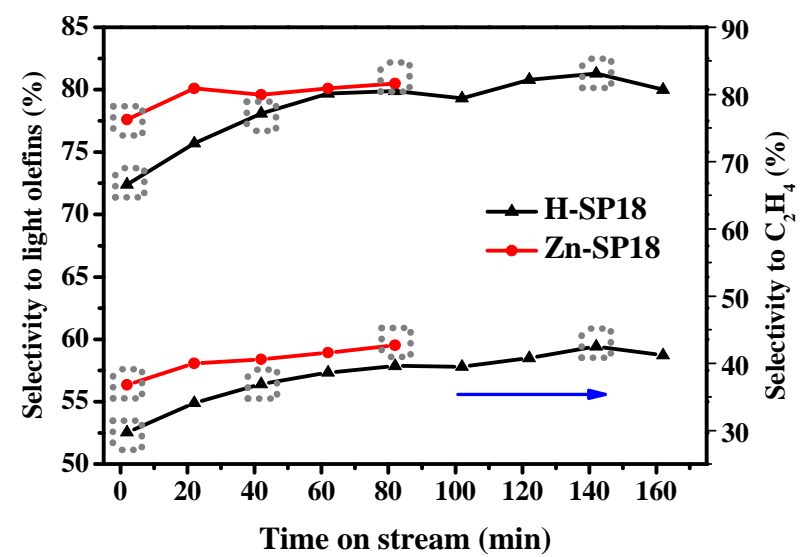

Fig. 3. The selectivity to $\mathrm{C}_{2} \mathrm{H}_{4}$ and light olefins over $\mathrm{H}-\mathrm{SP} 18$ and Zn-SP18. highest selectivity to light olefins) and H-SP18-HS also exhibit nearly identical product selectivity including the ethylene selectivity (Fig. S4), and the reaction time required to achieve the highest selectivity to light olefins (about 81\%) decreases from $142 \mathrm{~min}$ (H-SP18-HS) to $82 \mathrm{~min}$ (Zn-SP18-HS).

The products distribution as well as the ratio of $\mathrm{C}_{2} \mathrm{H}_{4}$ to $\mathrm{C}_{3} \mathrm{H}_{6}$ were further analysed. As shown in Figs. S5 and S6, the cavity modification via zinc ions incorporation remarkably enhances the selectivity to $\mathrm{C}_{2} \mathrm{H}_{4}$, and decrease the selectivity to hydrocarbons with relatively larger molecular size including $\mathrm{C}_{3} \mathrm{H}_{6}$, $\mathrm{C}_{3} \mathrm{H}_{8}, \mathrm{C}_{4}$ and $\mathrm{C}_{5}+$. Moreover, the cavity modification via zinc ions switches the major formation of propylene to comparable production of ethylene and propylene, and increases the initial ethylene/propylene ratio from 0.7 to 0.9 . In particular, the highest ethylene/propylene ratio of 1.1 is attained over Zn-SP18 catalysts with relatively shorter reaction time (82 min). As shown in Table S3, only trace amount of by-products are produced (the selectivity of $\mathrm{CO}$ and $\mathrm{CO}_{2}$ are $0.36 \%$ and $0.20 \%$, respectively), indicating that no obvious side reaction such as the decomposition of $\mathrm{CH}_{3} \mathrm{OH}$ is caused by the zinc ions $[19,33]$. Nevertheless, the catalyst lifespan of Zn-SP18 experiences a slight decrease (Fig. S7).

The correlation of product selectivity and carbon number over H-SP18-2min and Zn-SP18-2min are analysed. As shown in Fig. 4, the cavity modification via zinc ions incorporation effectively tunes the product selectivity, and switches the major formation of propylene over H-SP18-2min to comparable production of ethylene and propylene over Zn-SP18-2min, which makes the zinc cations modified SAPO-18 catalysts potential alternative catalysts in industrial MTO reaction.

\subsection{Initial period of MTO reaction}

The influences of the cavity modification via zinc ions in the product distribution in the initial period of MTO reaction are deeply investigated. As shown in Fig. 5, after MTO reaction for $20 \mathrm{~s}$, remarkably enhanced selectivity to ethylene from $11 \%$ over H-SP18 to $27 \%$ over Zn-SP18 is observed. By contrast to the slow increase in selectivity to ethylene over H-SP18, much higher selectivity to ethylene of about $31 \%$ are obtained over $\mathrm{Zn}$-SP18 at reaction time as short as $50 \mathrm{~s}$. The significantly en-

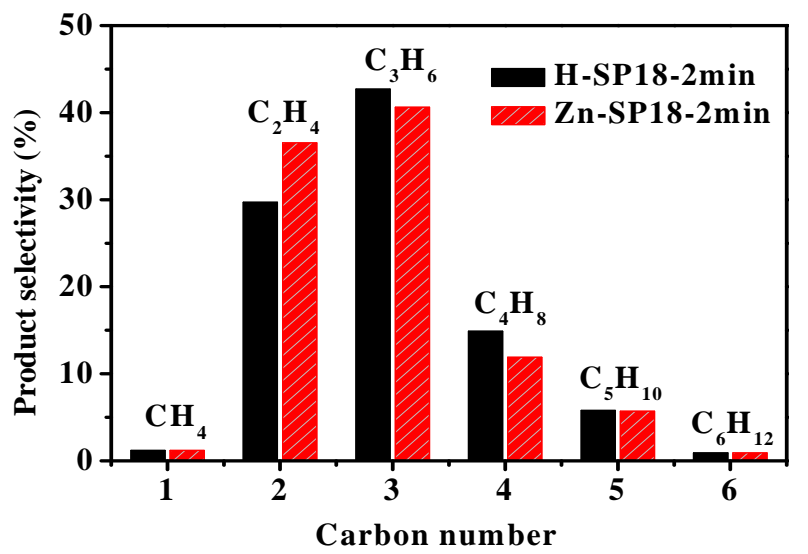

Fig. 4. The correlation of product selectivity and carbon number over H-SP18-2min and Zn-SP18-2min. 


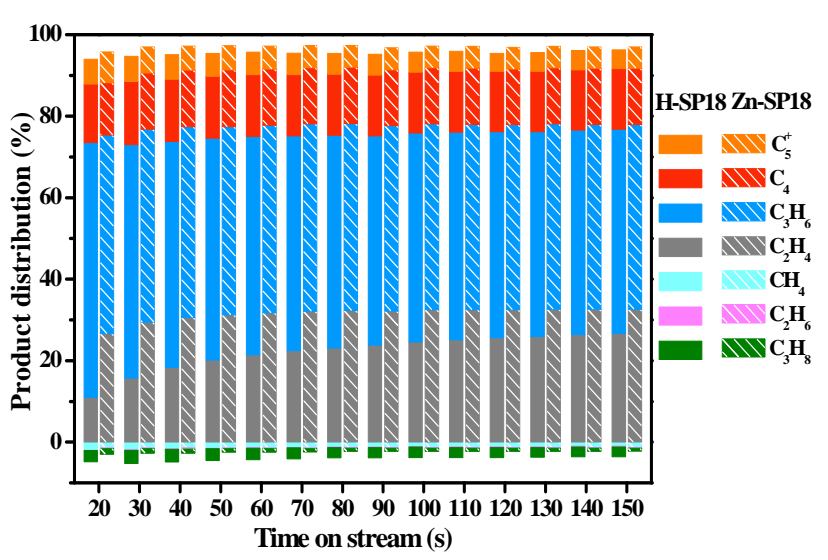

Fig. 5. The products distribution in the initial period of MTO reaction over H-SP18 and Zn-SP18.

hanced ethylene selectivity during the initial period of MTO reaction associated with the cavity modification via zinc ions effectively testifies the potential of zinc modified SAPO-18 catalysts in MTO reaction.

\subsection{Acidity}

The acidities of the as-prepared samples (H-SP18, Zn-SP18) are analyzed by $\mathrm{NH}_{3}$-TPD and ${ }^{1} \mathrm{H}$ MAS NMR. As seen in $\mathrm{NH}_{3}$-TPD profiles (Fig. S8), there are two desorption peaks at approximately $100-250$ and $300-500^{\circ} \mathrm{C}$ for all samples, which correspond to the weak and strong acid sites, respectively. In particular, Zn-SP18 exhibit relatively lower desorption temperature in strong acid sites, implying the relatively lowered strength of Brönsted acid sites of Zn-SP18 compared with H-SP18.

In addition, as shown in ${ }^{1} \mathrm{H}$ MAS NMR spectra (Fig. S9), signal at $3.6 \mathrm{ppm}$ is assigned to bridging hydroxyl groups, while signal at 1.6 with much lower intensity is assigned to $\mathrm{Si}(\mathrm{OH})$ $[34,35]$. By contrast to H-SP18, the signal density of Si(OH)Al of
Zn-SP18 decreased to some extent, indicating that part of the bridging hydroxyl groups are substituted by the zinc cations. It is generally believed that the catalysts possessing milder acidity facilitate the formation of propylene, owing to the inhibited hydrogen transfer reactions that consume propylene $[2,36]$. Thus the tuned product selectivity and enhanced selectivity to ethylene over Zn-SP18 with lower strength and concentration of Brönsted acid sites should be ascribed to the other influence factors instead of the acidity modification [19-21].

\subsection{Diffusion property}

\subsubsection{Chromatographic method}

For SAPO-34 catalyst, with the proceeding of MTO reaction, owing to the accumulation of large-sized carbonaceous species confined in the CHA cavity, the products suffer from increased diffusion hindrance, leading to remarkable product shape selectivity and enhanced selectivity to light olefins, especially ethylene [11,37]. Therefore, chromatographic method is adopted to evaluate the diffusion properties of probing molecules (ethylene and 1-butylene) in the as-prepared catalysts as well as the catalysts after MTO reaction. In the chromatographic method, the residence time distribution of probing molecules in the catalyst bed was calculated according to Eq. (1).

$$
E(t)=\frac{C(t)}{\int_{0}^{\infty} C(t) d t}
$$

Eq. 1. Residence time distribution (RTD) [t: retention time; $C(t)$ : the concentration of probing molecules diffused out of the catalyst bed] $[19,20]$.

As seen in Fig. 6, by comparison with H-SP18, relatively sharper RTD profiles with shorter residence time of ethylene and 1-butylene are obtained over Zn-SP18, which confirm the incorporation of $\mathrm{Zn}$ ions into the AEI cavities. In addition, by contrast to H-SP18-2min, sharper RTD profiles of ethylene and 1-butylene, especially 1-butylene, are observed over Zn-SP18-2min, implying increased diffusion hindrance are en-
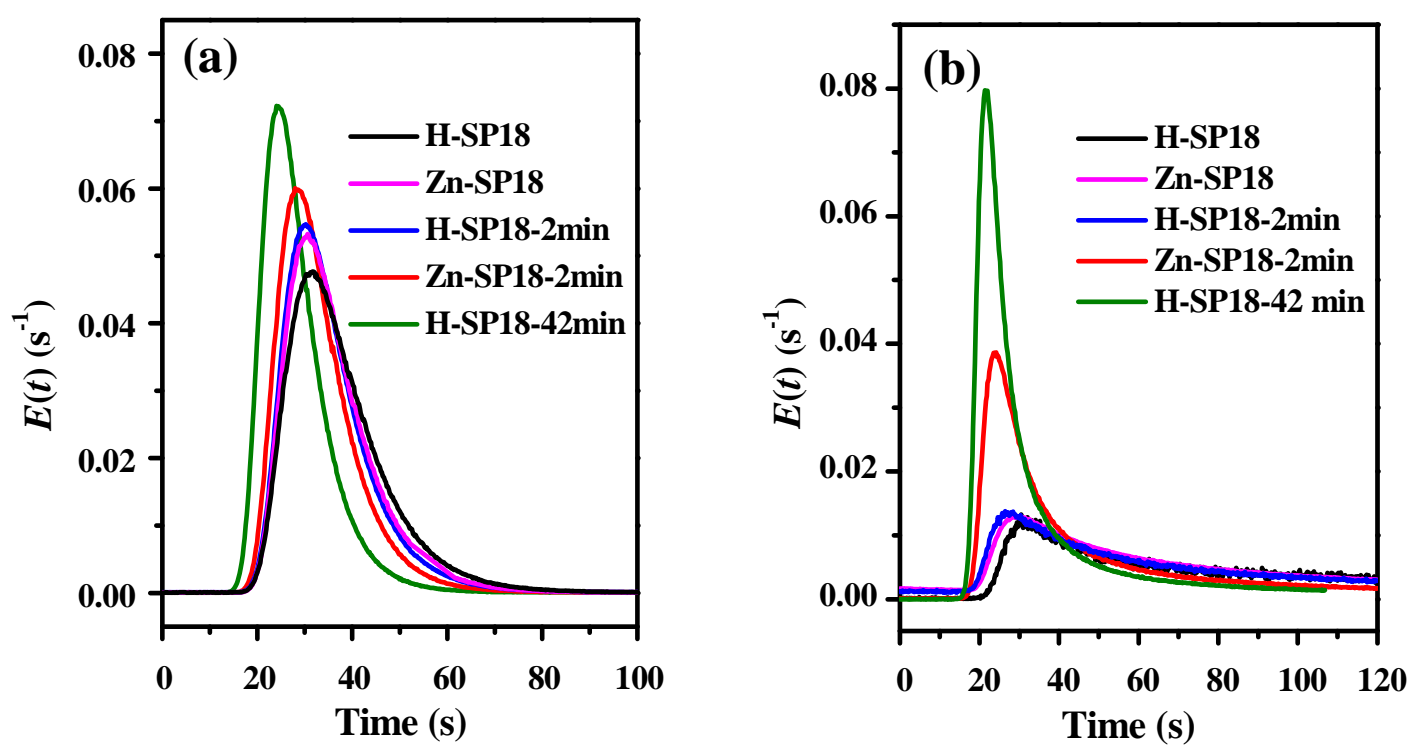

Fig. 6. The RTD of ethylene (a) and 1-butylene (b) in the catalyst beds containing the fresh or coked catalysts. 
countered for probing molecular over Zn-SP18-2min. There is no doubt that the large-sized hydrocarbons such as propylene, butylene and higher olefins exhibit smaller diffusivities compared with small-sized hydrocarbons (e.g ethylene) during the diffusion from the AEI cavities out to the gaseous phase [19-21]. Thus the bulky hydrocarbon encounter much higher diffusion limitation over Zn-SP18-2min than over H-SP18-2min, leading to increased selectivity to ethylene as well as light olefins over zinc ions modified SAPO-18 after the same reaction time (Figs. 3, S5 and S6).

Furthermore, the diffusion property of ethylene and 1-butylene in Zn-SP18-2min and H-SP18-42min was compared in depth. By contrast to Zn-SP18-2min, much sharper RTD profile are observed over H-SP18-42min, implying that markedly enhanced diffusion limitation are encountered for the generated products over H-SP18-42min compared with Zn-SP18-2min during the diffusion out of the AEI cavities to the effluent phase. Therefore, higher selectivity to ethylene and light olefins ought to be observed over H-SP18-42min compared with Zn-SP18-2min. Nevertheless, in our study, close product distributions are observed over H-SP18-42min and Zn-SP18-2min (Fig. S3), implying that factors in addition to the increased diffusion hindrance account for the enhanced selectivity to ethylene for zince modified SAPO-18 catalysts

\subsubsection{Intelligent gravimetric analysis}

IGA is also applied to investigate the diffusion property of probing molecule in fresh catalysts (H-SP18 and Zn-SP18), as well as catalysts with close product distributions after MTO reaction (Zn-SP18-2min and H-SP18-42min). Ethane is adopted as probing molecule considering the similar diffusivity relative to ethylene [38]. As shown in Fig. 7, Zn-SP18 displays decreased saturation adsorption capacities of ethane compared with H-SP18, indicating the zinc ions incorporation in the AEI cavity of SAPO-18, which is in agreement with the slight decreased pore volume (Table S1).

Moreover, H-SP18-42min exhibit decreased saturation adsorption capacities of ethane compared with Zn-SP18-2min. The diffusion properties of ethane in the crystals are attained from the Fick's second law (Eq. S1) [39]. As shown in Fig. S10, by contrast to Zn-SP18-2min, the normalized adsorption amount of ethane on H-SP18-42min is lower (in a short time domain under $10 \mathrm{mba}$ ), thus the characteristic diffusion time $\left(\mathrm{D} / \mathrm{r}^{2}\right)$ of H-SP18-42min should be lower than that of Zn-SP18-2min. Considering the same characteristic diffusion length, the diffusivity of ethane for H-SP18-42min is lower than that for Zn-SP18-2min. Thus, the generated products in MTO reaction over H-SP18-42min might encounter increased diffusion hindrance compared with Zn-SP18-2min during the diffusion out of the AEI cavities to the effluent phase. Combined with the fact that lower diffusivity for products with larger molecular size (e.g propylene and higher olefins) [19-21], enhanced selectivity to ethylene should be observed over H-SP18-42min. However, close product distribution between H-SP18-42min and Zn-SP18-2min are observed (Fig. S3), therefore, in addition to the increased diffusion restriction, other influential factors play important and extra role in the enhanced ethylene selectivity over zinc ion modified SAPO-18 catalysts, which is in consistence with the conclusion drawn from chromatographic method analysis.

\subsection{Analysis of carbonaceous species}

The carbonaceous species retained in catalysts are extracted and analyzed by GC-MS. As seen in Fig. 8, methyl-substituted benzenes can be found in H-SP18-2min, with tetramethyl-benzene and pentamethyl-benzene being the major species. After the cavity modification via zinc ions, the methylbenzenes with one to three methyl groups are the major species. It has been demonstrated that the generation of ethylene is promoted by the methylbenzenes with two or three methyl groups, while propylene is facilitated by the methylbenzenes with four to six methyl groups $[40,41]$. Therefore, the formation of lower methylbenzenes after zinc ion modification is beneficial for the ethylene formation, leading to the increased ethylene selectivity.

Furthermore, enhanced amount of hydrogen-deficient bicyclic aromatic compound such as naphthalenes and methylnaphthalenes are observed over Zn-SP18-2min. Therefore, the incorporated zinc cations promote the generation of naphthalene and derivatives, and enhanced the diffusion limitation, which effectively tune the product selectivity and switch the
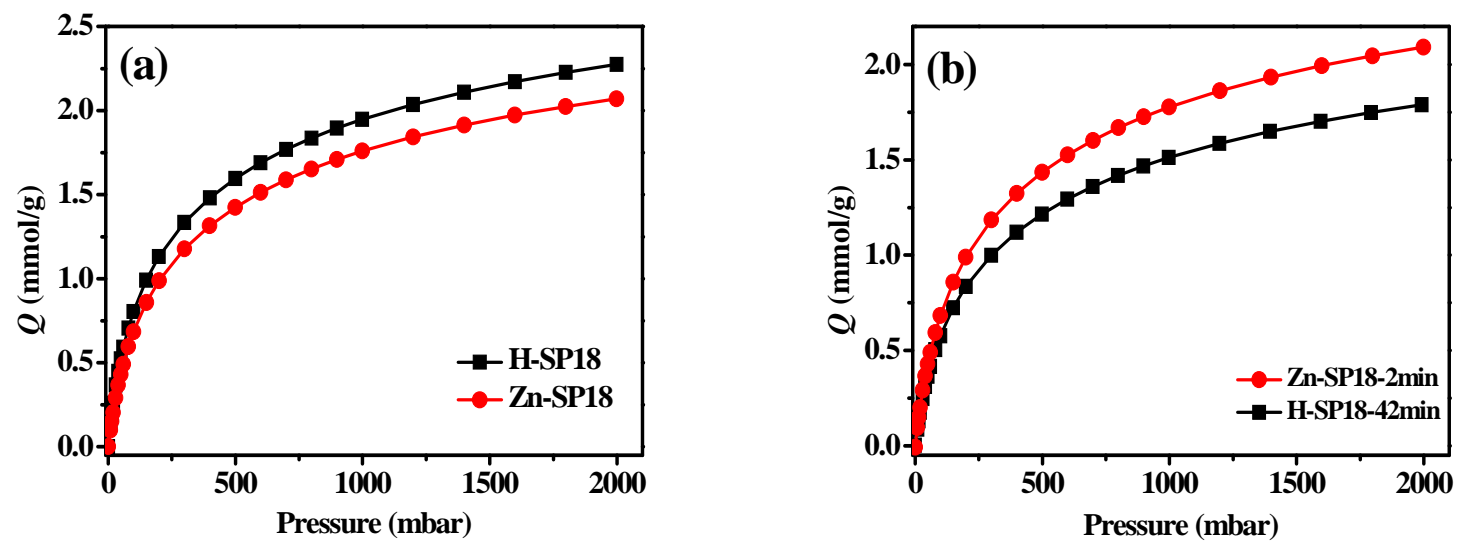

Fig. 7. The ethane adsorption isotherms on the as-prepared H-SP18 and Zn-SP18 (a), and the coked H-SP18-42min and Zn-SP18-2min (b). 


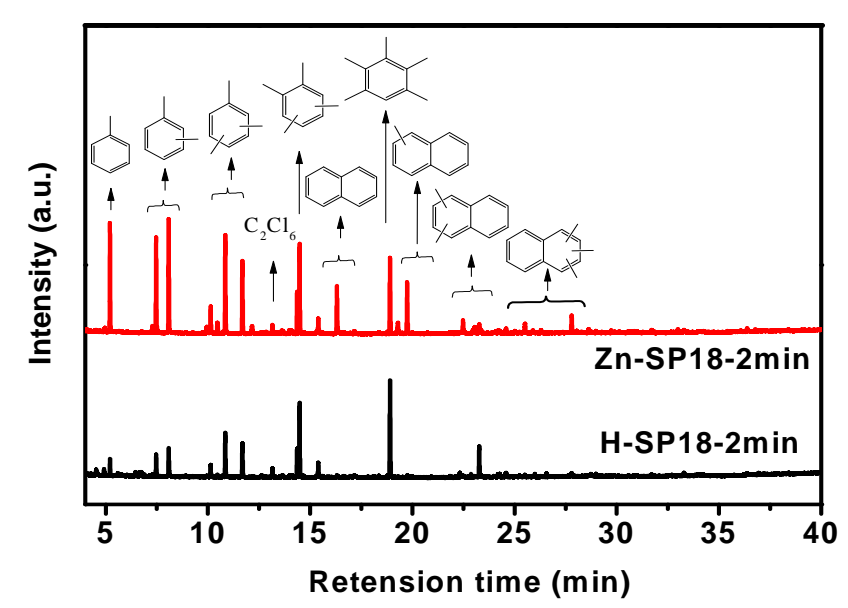

Fig. 8. Coke species in H-SP18 and Zn-SP18 after 2 min. Reaction conditions: $480^{\circ} \mathrm{C}$, WHSV $=2.0 \mathrm{~h}^{-1}, 40 \% \mathrm{CH}_{3} \mathrm{OH}$ solution.

\section{Table 2}

The relationship between the selectivity of light olefins and the amount of carbon deposit over H-SP18 and Zn-SP18.

\begin{tabular}{lccc}
\hline Sample & TOS & Coke amount & Sel. to light olefins \\
\hline H-SP18-2min & 2 & 0.9 & 72.4 \\
Zn-SP18-2min & 2 & 1.0 & 77.6 \\
H-SP18-42min & 42 & 3.7 & 78.1 \\
H-SP18-HS & 142 & 13.8 & 81.3 \\
Zn-SP18-HS & 82 & 10.4 & 80.5 \\
\hline
\end{tabular}

major formation of propylene to comparable production of ethylene and propylene.

The relationship between the selectivity of light olefins and the amount of carbon deposit are analyzed and shown in Table 2. After the methanol conversion for $2 \mathrm{~min}$, by contrast to the H-SP18-2min with coke amount of 0.9 wt\%, over Zn-SP18-2min, enhanced selectivity to light olefins (approximately $77 \%$ ) are obtained, with nearly the same amount of carbon deposit (1.0 wt\%). Furthermore, by comparison with Zn-SP18-2min (Fig. S3), much larger coke amount are observed over H-SP18-42min, indicating that close selectivity to light olefins, especially ethylene can be obtained over zinc modified SAPO-18 catalyst with significant reduction in carbon atom consumption as well as reaction time. In addition, over Zn-SP18-HS, the highest selectivity to light olefin of about $80 \%-81 \%$ can be obtained with markedly lower coke deposition (coke amount of $10.4 \mathrm{wt} \%$ ), by contrast to H-SP18-HS (coke amount of $13.8 \mathrm{wt} \%$ ). Therefore, the cavity modification of SAPO-18 catalysts via zinc ions incorporation not only effectively tune the product selectivity, enhance the selectivity to ethylene and light olefins, but also fulfill the green requirement of carbon atom economy by means of achieving the same catalytic performance with less coke deposition [42].

\section{Conclusions}

The AEI cavity of SAPO-18 catalyst was modified with zinc ions with the conventional ion exchange procedure. The zinc ions accommodation as well as the generation of bicyclic aromatic species in the AEI cavity of SAPO-18 catalyst introduce additional diffusion hindrances that exert greater influence on the bulky products, which increase the selectivity to small-sized products such as ethylene, and shifts the products from mainly propylene to comparable production of ethylene and propylene in MTO reaction. The incorporated zinc ions facilitate the generation of lower methylbenzenes which favours the ethylene formation. An effective strategy via cavity modification to switch the product selectivity and enhance the selective to ethylene and light olefins is thus proposed, for SAPO molecular sieves with relatively larger cavity in the MTO reaction, which provide a potential direction to develop the alternative to SAPO-34 catalysts for industrial MTO application.

\section{References}

[1] P. Tian, Y. X. Wei, M. Ye, Z. M. Liu, ACS Catal., 2015, 5, 1922-1938.

[2] S. T. Xu, Y. C. Zhi, J. F. Han, W. N. Zhang, X. Q. Wu, T. T. Sun, Y. X. Wei, Z. M. Liu, Adv. Catal., 2017, 61, 37-122.

[3] K. Khanmohammadi, S. Amani, A. B. Garmarudi, A. Niaei, Chin. J. Catal., 2016, 37, 325-339.

[4] X. B. Zhao, Y. Hong, L. Y. Wang, D. Fan, N. N. Yan, X. N. Liu, P. Tian, X. W. Guo, Z. M. Liu, Chin. J. Catal., 2018, 39, 1418-1426.

[5] J. W. Zhong, J. F. Han, Y. X. Wei, P. Tian, X. W. Guo, C. S. Song, Z. M. Liu, Catal. Sci. Technol., 2017, 7, 4905-4923.

[6] S. Ren, G. J. Liu, X. Wu, X. Q. Chen, M. H. Wu, G. F. Zeng, Z. Y. Liu, Y. H. Sun, Chin. J. Catal., 2017, 38, 123-130.

[7] Y. Zhou, L. Qi, Y. X. Wei, C. Y. Yuan, M. Z. Zhang, Z. M. Liu, Chin. J. Catal., 2016, 37, 1496-1501.

[8] U. Olsbye, S. Svelle, K. P. Lillerud, Z. H. Wei, Y. Y. Chen, J. F. Li, J. G. Wang, W. B. Fan, Chem. Soc. Rev., 2015, 44, 7155-7176.

[9] J. F. Haw, W. G. Song, D. M. Marcus, J. B. Nicholas, Acc. Chem. Res., 2003, 36, 317-326.

[10] I. Yarulina, A. D. Chowdhury, F. Meirer, B. M. Weckhuysen, J. Gascon, Nat. Catal., 2018, 1, 398-411.

[11] U. Olsbye, S. Svelle, M. Bjorgen, P. Beato, T. V. W. Janssens, F. Joensen, S. Bordiga, K. P. Lillerud, Angew. Chem. Int. Ed., 2012, 51, 5810-5831.

[12] J. R. Chen, J. Z. Li, Y. X. Wei, C. Y. Yuan, B. Li, S. T. Xu, Y. Zhou, J. B. Wang, M. Z. Zhang, Z. M. Liu, Catal. Commun., 2014, 46, 36-40.

[13] J. Z. Li, Y. X. Wei, J. R. Chen, S. T. Xu, P. Tian, X. Yang, B. Li, J. B. Wang, Z. M. Liu, ACS Catal., 2015, 5, 661-665.

[14] R. Martínez-Franco, Z. B. Li, J. Martinez-Triguero, M. Moliner, A. Corma, Catal. Sci. Technol., 2016, 6, 2796-2806.

[15] R. Wendelbo, D. Akporiaye, A. Andersen, I. M. Dahl, H. B. Mostad, Appl. Catal. A, 1996, 142, L197-L207.

[16] K. Ono, K. Miyake, M. Nakai, H. Al Jabri, Y. Hirota, Y. Uchida, S. Tanaka, M. Miyamoto, N. Nishiyama, Catal. Sci. Technol., 2017, 7, 4622-4628.

[17] R. L. Smith, S. Svelle, P. del Campo, T. Fuglerud, B. Arstad, A. Lind, S. Chavan, M. P. Attfield, D. Akporiaye, M. W. Anderson, Appl. Catal. A, 2015, 505, 1-7.

[18] Z. Q. Xu, J. W. Li, W. X. Qian, H. F. Ma, H. T. Zhang, W. Y. Ying, RSC Adv., 2017, 7, 54866-54875.

[19] J. W. Zhong, J. F. Han, Y. X. Wei, S. T. Xu, Y. L. He, Y. J. Zheng, M. Ye, X. W. Guo, C. S. Song, Z. M. Liu, Chem. Commun., 2018, 54, 3146-3149.

[20] J. W. Zhong, J. F. Han, Y. X. Wei, S. T. Xu, T. T. Sun, X. W. Guo, C. S. Song, Z. M. Liu, J. Energy Chem., 2018, DOI: 10.1016/j.jechem.2018.07.017.

[21] J. W. Zhong, J. F. Han, Y. X. Wei, S. T. Xu, T. T. Sun, X. W. Guo, C. S. Song, Z. M. Liu, Chin. J. Catal., 2018, 39, 1821-1831. 


\title{
Graphical Abstract
}

Chin. J. Catal., 2019, 40: 477-485 doi: S1872-2067(19)63281-X

\section{Tuning the product selectivity of SAPO-18 catalysts in MTO reaction via cavity modification}

Jiawei Zhong, Jingfeng Han, Yingxu Wei*, Shutao Xu, Tantan Sun, Shu Zeng, Xinwen Guo, Chunshan Song, Zhongmin Liu *

Dalian Institute of Chemical Physics, Chinese Academy of Sciences, China; Dalian University of Technology, China; Pennsylvania State University, USA; University of Chinese Academy of Sciences, China

The AEI cavity of SAPO-18 catalysts was modified with zinc cations. The cavity modification tunes the product selectivity, and shifts the products from mainly propylene to comparable production of ethylene and propylene in MTO reaction.

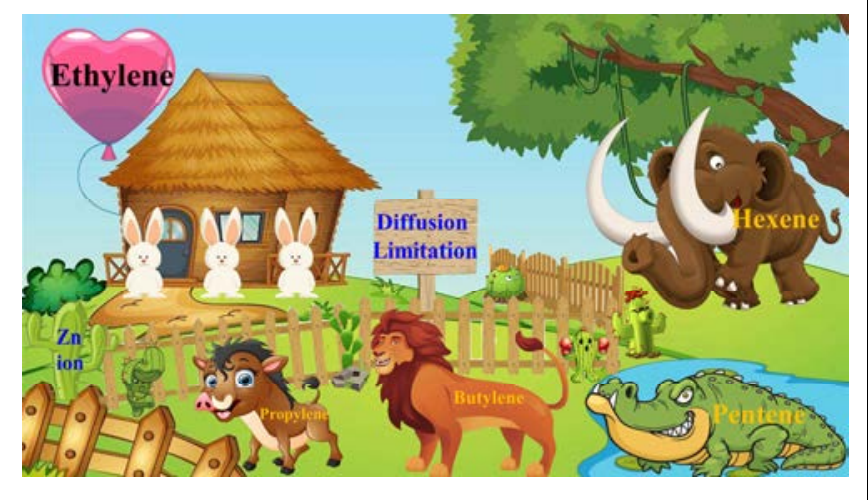

croporous Mesoporous Mater., 2008, 114, 416-423.

[33] D. R. Dubois, D. L. Obrzut, J. Liu, J. Thundimadathil, P. M. Adekkanattu, J. A. Guin, A. Punnoose, M. S. Seehra, Fuel Process Technol., 2003, 83, 203-218.

[34] W. L. Dai, M. Scheibe, L. D. Li, N. J. Guan, M. Hunger, J. Phy. Chem. C, 2012, 116, 2469-2476.

[35] J. R. Chen, J. Z. Li, C. Y. Yuan, S. T. Xu, Y. X. Wei, Q. Y. Wang, Y. Zhou, J. B. Wang, M. Z. Zhang, Y. L. He, S. L. Xu, Z. M. Liu, Catal. Sci.Technol., 2014, 4, 3268-3277.

[36] D. Chen, K. Moljord, A. Holmen, Microporous Mesoporous Mater., 2012, 164, 239-250.

[37] B. P. C. Hereijgers, F. Bleken, M. H. Nilsen, S. Svelle, K. P. Lillerud, M. Bjorgen, B. M. Weckhuysen, U. Olsbye, J. Catal., 2009, 264, 77-87.

[38] D. H. Olson, M. A. Camblor, L. A. Villaescusa, G. H. Kuehl, Microporous Mesoporous Mater., 2004, 67, 27-33.

[39] J. J. Zheng, Q. H. Zeng, Y. Y. Zhang, Y. Wang, J. H. Ma, X. W. Zhang, W. F. Sun, R. F. Li, Chem. Mater., 2010, 22, 6065-6074.

[40] W. G. Song, H. Fu, J. F. Haw, J. Am. Chem. Soc., 2001, 123, 4749-4754.

[41] W. G. Song, H. Fu, J. F. Haw, J. Phy. Chem. B, 2001, 105, 12839-12843.

[42] Y. X. Wei, C. Y. Yuan, J. Z. Li, S. T. Xu, Y. Zhou, J. R. Chen, Q. Y. Wang, L. Xu, Y. Qi, Q. Zhang, Z. M. Liu, ChemSusChem, 2012, 5, 906-912.

\section{修饰SAPO-18分子篮的笼结构以调变甲醇制烯烃反应的产物选择性}

\author{
钟家伟 ${ }^{\mathrm{a}, \mathrm{b}, \mathrm{d}}$, 韩晶峰 ${ }^{\mathrm{a}}$, 魏迎旭 ${ }^{\mathrm{a}, \#}$, 徐舒涛 ${ }^{\mathrm{a}}$, 孙毯毯 ${ }^{\mathrm{a}}$, 曾 姝, 郭新闻 ${ }^{\mathrm{b}}$, 宋春山 ${ }^{\mathrm{b}, \mathrm{c}}$, 刘中民 ${ }^{\mathrm{a},{ }^{*}}$ \\ ${ }^{\mathrm{a}}$ 中国科学院大连化学物理研究所, 甲醇制烯烃国家工程实验室, 国家能源低碳催化与工程研发中心, \\ 洁净能源国家实验室，能源材料化学协同创新中心，辽宁大连116023，中国 \\ ${ }^{\mathrm{b}}$ 大连理工大学化工学院, 宾州州立大学-大连理工大学联合能源研究中心, 精细化工国家重点实验室, 辽宁大连116024, 中国 \\ c 宾州州立大学, 宾夕法尼亚州16802, 美国 \\ d中国科学院大学, 北京100049, 中国
}

摘要: 低碳烯烃(乙烯、丙烯)是重要化工材料的基础原料. 甲醇制烯烃(MTO)技术是重要的非石油路线制取低碳烯烃技术. SAPO-34分子篮在MTO反应中表现出优异的低碳烯烃选择性, 而笼结构尺寸较大的SAPO-18分子篮的MTO反应产物以丙 烯为主. 乙烯具有比丙烯更高的经济附加值, 因此提升SAPO-18分子篎MTO反应中乙烯的选择性有着重要的工业意义.

本文采用离子交换法对SAPO-18分子篮进行金属Zn改性, 修饰SAPO-18分子篎的笼结构. 利用多种手段对Zn改性 SAPO-18分子篮的物理结构、金属物种状态及分布、酸性、扩散性质等进行表征, 对积碳物种的种类、积炭量等进行分析, 
从而关联SAPO-18分子篮笼结构的修饰与MTO反应产物选择性的关系.

首先, 我们对Zn改性SAPO-18分子篮的物理结构进行分析. X射线衍射表明, 所采用的SAPO-18为不含杂晶的纯相分 子篮. $\mathrm{N}_{2}$ 物理吸附-脱附表明, 离子交换法法保持SAPO-18分子篮比表面积和孔体积. 其次, 我们考察了Zn改性SAPO-18分 子篮中金属物种的状态及分布. X射线光电子能谱(XPS)表明, $\mathrm{Zn}$ 物种主要以孤立态的 $\mathrm{Zn}^{2+}$ 阳离子形式存在. XPS和X射线 苂光结合表明, Zn阳离子改性SAPO-18分子篮表层富 $\mathrm{Si}$ 富Zn, 呈类核壳结构. 氨气-程序升温脱附与核磁共振氢谱结合表 明, Zn改性SAPO-18分子篎酸性位点的酸量降低. 继而对Zn改性SAPO-18分子篮的扩散性质进行分析. 色谱法和智能重量 分析表明, Zn阳离子的引入增加探针分子的扩散限制, 从而推断增加MTO反应产物的扩散限制. 色质谱联用表明, Zn阳离 子的引入促进低甲基苯的生成, 利于乙烯产物的生成; 同时促进双环芳烃的形成, 增加MTO反应产物的扩散限制. 热重表 明, Zn阳离子改性SAPO-18分子篮以更低的积炭量达到同样的MTO反应催化效果, 符合碳原子经济性.

Zn阳离子改性有效修饰SAPO-18分子篎的笼结构, 表层富 $\mathrm{Si}$ 和Zn, 呈现类核壳结构, 增加了对MTO反应产物的扩散限 制, 尤其对分子尺寸较大的反应产物, 从而调变MTO反应选择性. 因此, Zn阳离子改性有效修饰了 SAPO-18分子篎的笼结 构, 增加乙烯选择性和乙烯/丙烯比, 将产物分布以丙烯为主调变为乙烯和丙烯选择性相近.

关键词: SAPO-18; 甲醇制烯烃; 产物选择性; 笼结构修饰

收稿日期: 2018-11-13. 接受日期: 2018-12-19. 出版日期: 2019-04-05.

*通讯联系人. 电话: (0411)84379998; 传真: (0411)84379289; 电子信箱: liuzm@dicp.ac.cn

”通讯联系人. 电话: (0411)84379118; 传真: (0411)84379289; 电子信箱: weiyx@dicp.ac.cn

基金来源：中国科学院前沿科学重点研究计划(QYZDY-SSW-JSC024); 国家自然科学基金(21603223, 21473182,91334205, 91545104); 中国科学院青年创新促进会(2014165).

本文的电子版全文由Elsevier出版社在ScienceDirect上出版(http://www.sciencedirect.com/science/journal/18722067). 